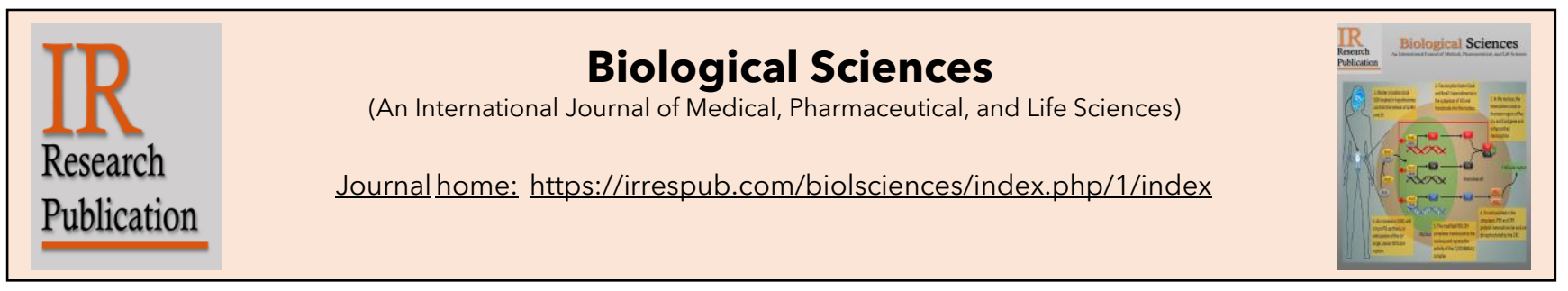

\title{
Micro-needles as an effective drug delivery system and associated patents in pharmaceutical field: A Review
}

Sumel Ashique ${ }^{\star \star}$, Vaibhavi mittal', Tahamina Khatun², Aakash Upadhyay1, Suryakant Verma' ${ }^{1}$, Sachin Tyagi ${ }^{1}$, Asif Iqbal', Imrul Kayes ${ }^{3}$

${ }^{1}$ Department of Pharmaceutics, Bharat Institute of Technology, Meerut, Uttar Pradesh, India

${ }^{2}$ Department of Life Science, Katiahat B.K.A.P Institution, West Bengal, India

${ }^{3}$ Department of Pharmacology, Dr. B.C. Roy College of Pharmacy \& Allied Health Science, West Bengal, India

\section{ARTICLE HISTORY}

Received: 16-04-2021

Revised: 19-04-2021

Accepted: 20-04-2021

Online: 23-04-2021

\section{KEYWORDS}

Microneedles

Fabrication

Drug delivery system,

Patents

\section{ABSTRACT}

Microneedles (MNs) are the most interesting and minimally invasive technique in pharmaceutical drug delivery systems. Recently researchers have concluded that MNs can be prominent future methods. Depending on the unique properties of MNs, they can be used widely in drug delivery systems. This delivery method has improved drug delivery avoiding many hurdles that were linked with the conventional system. The principal mechanism involved is temporarily damaging the skin layer; hence micron-size pores are created, which help the drug to reach the targeted site without any complications. The popularity of $\mathrm{MNs}$ in pharmaceutical and biomedical research is growing exponentially as it offers easy delivery of bio-actives to the specific site with minimal invasion. Several numbers of molecules are delivering via MNs, such as hormones, vaccines, and peptides. In this review, the efficiency of Micro-needle, their fabrication materials, as drug delivery carriers, and various associated patents are discussed.

\section{Introduction}

Several procedures are there to deliver bio-actives in

*Address for correspondence

Department of Pharmaceutics, Bharat Institute of Technology, Meerut, Uttar Pradesh, India; Email: ashiquesumel007@gmail.com

DOI: http://dx.doi.org/10.55006/biolsciences.2021.1106 Published by IR Research Publication; Ashique S et al ( 2021 by Biological Sciences is licensed under CC BY ${ }_{4.0}(0)(1)$ the specific portion of the body, but among this oral drug delivery system has been widely received because of having an easy mode of administration and better patient compliance [1]. But sometimes, this oral drug administration is unable to cross some specific limitations from our physiological system, and thus the importance of other delivery systems has become into consideration. For example, transdermal drug delivery system (TDDS) where the drugs are administered via external stratum corneum (SC) [2]. This outmost layer is the primary blockade for topically administered formulations. It permits the drug(s) only with (molecular weight < $500 \mathrm{Da}$ ) and having lipophilic nature and low melting point in nature. Hence, to conquer the complication from the last decades, researchers are 
giving an eye to MNs technology which can easily reach the dermis layer with eliciting minimum pain to the patient [3]. MNs systems have become a popular option due to offering many advantages over conventional drug delivery systems [4], [5], such as transferring drug molecules by skin barriers without causing any permanent tissue damage and pain. Gerstel and Place firstly conceived this technology for the passage of bio-actives in 1971. At first, MNs were used as a puncturing tool, but later in the 1990s it was used as a drug delivery carrier. It provides a sooner healing rate compared to conventional procedures by bypassing the firstpass metabolism of the therapeutics and hence can attain safe and effective pharmacokinetics and pharmaco-dynamics response. Even though MNs can deliver high molecular weight components in a controlled manner at the targeted site, which is widely accepted in pharmaceutical drug applications. MNs produce micron-sized channels for the deliverance of therapeutics. Generally, the MNs can easily reach the dermis layer without touching the nerves. They are $100 \mu \mathrm{m}$ lengthy, 1-50 $\mu \mathrm{m}$ wide at the tip, and about 50 to $300 \mu \mathrm{m}$ at the base [6]. Micro-needles are fabricated from a wide diversity of components, including metal, polymer, glass, silicone, and hydrogel. Though having many applications in the pharmaceutical field but in targeted delivery, DNA, protein delivery, it is necessary to explore more [7]. In Figure 1 various drug delivery system along with Micro-needles (MNs) has been described.

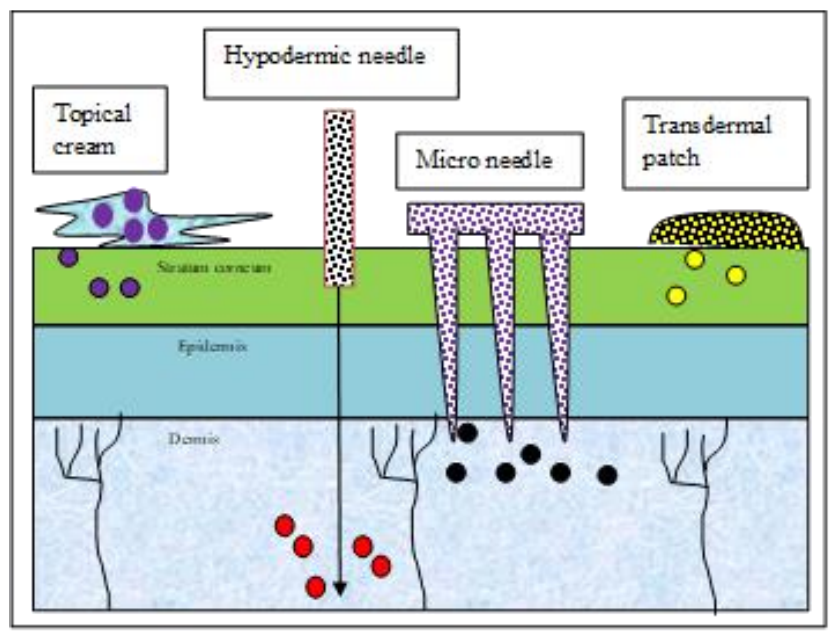

Figure 1. Description: Comparison between various drug delivery systems

\section{Fabrication of MNs}

Different types of components are used to prepare MNs. It uses polymeric substances such as natural, biodegradable, non-biodegradable, and metals [8], [9]. The basic requirements for polymers, metals, and metalloids are biocompatibility and good mechanical properties [10]. It must provide chemical resistance and show important physical characters that can make MNs a multipurpose material for the pharmaceutical field [11]. Especially the polymeric MNs or dissolvable MNs, the material must control the release of drug (like controlled or in a sustained manner) [12]. As an alternative, MNs that are made up of polymeric material must follow the prerequisite of $\mathrm{MNs}$ [13]. The first $\mathrm{MN}$ was developed from silicon in the 1990s. Generally, the foremost used metals are stainless steel and titanium, even though palladium, nickel can also be applied. Metals offer good mechanical strength and are biocompatible. They are strong enough to evade breaking associated problems inside the body, therefore more appropriate than siliconbased MNs. Titanium is a better substitute for stainless steel [14]. Alumina is mostly applied because of having good chemical-resistant properties. It produces stable oxide due to having strong ionic and covalent bonds between $\mathrm{Al}$ and $\mathrm{O}$ atoms [15]. Other ceramics utilized such as calcium sulfate dehydrate and calcium phosphate dehydrate. In recent years an organically modified ceramic called Ormocer $^{\circledR}$ has been used. It is a three-dimensional cross-linked copolymer [16]. A broad variety of polymers are used such as polymethyl methacrylate, poly-lactic acid, poly-lactic-coglycolic acid, cyclic-olefin copolymer, poly vinylpyrrolidone, are also used to develop microneedles [17], [18], [19], [20], [21]. Maltose is generally used sugars, and other types of sugars are including mannitol, sucrose, xylitol, and galactose, may also be used. Mould is prepared by using carbohydrate slurries with the help of silicon or metal templates. The drug-encapsulated carbohydrate mixture is cast into the molds to produce MNs [22]. Table 1 described about various casting methods of MNs development [23], [24], [25].

\section{Method of drug delivery}

Topical delivery of bio-actives through skin via diffusion process. Micro-needle provisionally damages the skin tissue. The device is developed by arranging hundreds of MNs in arrays on a tiny patch to transport enough bio-active to show the required therapeutic response. It crosses the stratum corneum, thus bypassing the layer easily. The drug goes straight to the desired place and into the systemic circulation and gives a therapeutic action [26], [27]. The mechanism of drug delivery through MNs is depicted in Figure 2.

\section{Types of MNs}

Various types of MNs are investigated to use in drug 


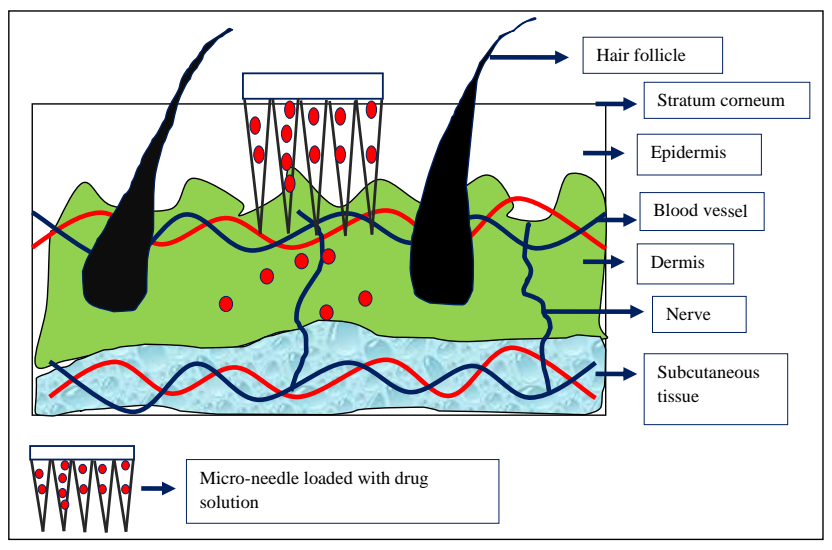

Figure 2. Micro needle device with drug solution then device inserted into the skin thus temporary mechanical disruption of the skin then releasing the drug in the epidermis and finally transport of drug to the site of action.

delivery systems, including solid, coated, dissolving, hollow, and hydrogel MNs. Such MNs with their drug release mechanism is described in Figure 3, where each of them has its own mechanism to transport the drug into the epidermis. Few of them are applied to create pores in the stratum corneum, some are pre-coated with the drug solution on to their surface, and some are prefilled with drug solution [28], [29].

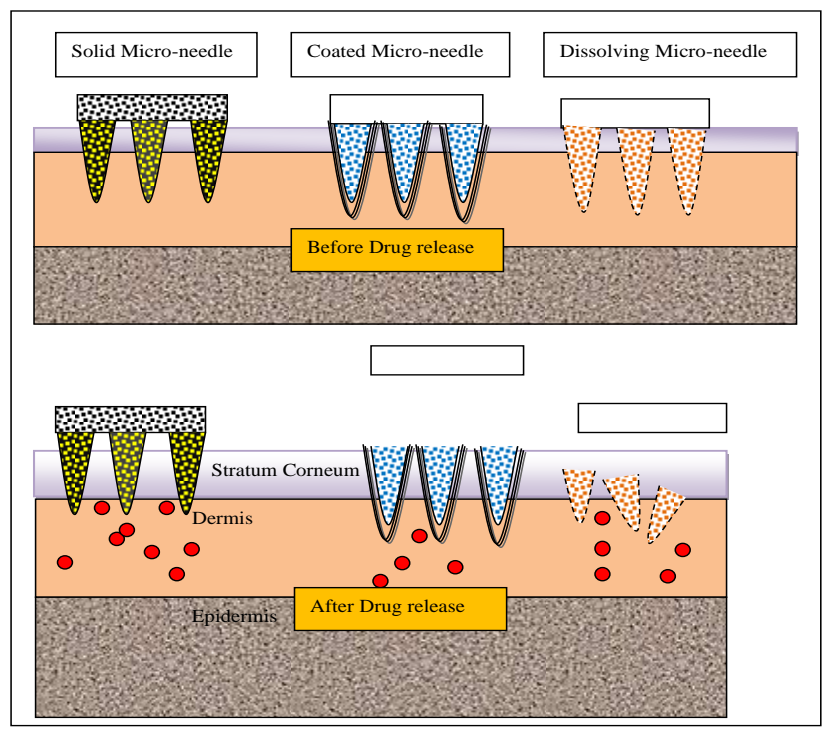

Figure 3. Description: Different types of Micro-needles and drug release mechanism

\section{Methods of delivering drug}

Different options are used to transport the drug into the epidermis layer. One mechanism is to make holes, and then a drug-holding patch is placed in the hole, which involves straight transportation of therapeutics into the target site; an electric field is applied to get a better result. The second mechanism is to coat the $\mathrm{MN}$ drug-containing solvent that is inserted into the skin where the drug gets dissolved. The third method is to immerse the MNs into the drug dissolving solution and then rub the needles on the skin. Another approach is to encapsulate the drug into a biodegradable polymer and develop the MNs. In the case of the hollow MN, the drug reached solution is filled into the hollow space [30], [31]. Drug-encapsulated biodegradable MNs have been broadly applied for the active delivery of drug moieties [32].

\section{Application of MNs in drug delivery system}

Various research studies are going on to check the efficacy of $\mathrm{MNs}$ in various parts of the pharmaceutical and biomedical fields. This system offers excellent drug, protein, and peptide encapsulation for their controlled or sustained release in the specific site. Not only in transdermal drug delivery but also act as a tremendous mechanism for drug delivery via nail, nasal, ocular, and ear. A variety of pharmaceutical applications of MNs have been discussed below.

\section{Oligonucleotide delivery}

The major challenge of this DNA or RNA-based molecule is the intracellular site of action; hence, several methods are used to improve the movement of the molecule. For example, 20 merphosphorothioated oligo-deoxynucleotide was delivered by using the MNs technique. Solid MNs are basically used to deliver oligonucleotide by creating the pore with patch approach. It was found that more amount of drug is reaching at the required site as compared to the intact skin. By applying the iontophoresis mechanism with the MNs technique provided greater results than iontophoresis alone [33], [34].

\section{Vaccine therapy}

This biological preparation gives acquired immunity to a specific disease. Basically, the vaccine boosts the immune system and offers defence against future infection. MNs method provided effective results in vaccine therapy [35]. For example, DNA vaccine was delivered by utilizing MNs. The immune response showed far better than normal injections. Even a MN-based influenza vaccine was also made to administer [36], [37]. A lower dose is required when the bio-active moiety is given via hollow MNs in comparison with intramuscular injection. Anthrax and rabies vaccine was given through hollow MN. Ogai and co-workers developed hollow MNs by using poly-glycolic acid to improve the efficacy by the intradermal route. Dissolving MNs were also tested for intradermal vaccination [38]. Zhu et al. conducted the stability of a vaccine-loaded MN and 
Table 1. Different casting methods for developing Micro-needles

\begin{tabular}{|c|c|}
\hline Type of MNs & Method of fabrication \\
\hline Silicon MNs & $\begin{array}{r}\text { Micro-electromechanical systems (MEMS) techniques, thin-film deposition on a substrate, chemical vapor } \\
\text { deposition on a substrate, Silicon dry-etching process, lsotropic etching, etc. }\end{array}$ \\
\hline Metal MNs & $\begin{array}{r}\text { Three-dimensional laser ablation, laser cutting (stainless less), metal electroplating methods (palladium), } \\
\text { wet etching photochemical etching (titanium), etc. }\end{array}$ \\
\hline Ceramic MNs & Ceramic micro molding and sintering lithography, etc. \\
\hline Coated MNs & Dipping or spraying, layer-by-layer (LbL) coating techniques \\
\hline Hollow MNs & fabrication, Integrated lithographic molding technique, etc. \\
\hline Dissolving MNs & Photolithography, micro molding, casting, hot embossing, injection molding, investment molding, etc. \\
\hline Polymeric MNs &
\end{tabular}

concluded that trehalose resulted in considerably higher stability rather than sucrose and that $80 \%$ of the early antigenicity was retained under stress conditions ( $60^{\circ} \mathrm{C} / 3$ months) [39]. To further boost immunogenicity, an immune-modulatory cytokine, granulocyte-macrophage colony-stimulating factor (GM-CSF), was utilized to MNs to persuade a longlived antibody action. For stable and effective transport of GM-CSF, a microneedle using trehalose, CMC, or gelatine was used [40]. A thirdgeneration hepatitis vaccine MN that contains $15 \%$ trehalose showed enhanced stability rather than conventional liquid formulations, including stability for 1 week at $40^{\circ} \mathrm{C}[41]$.

\section{Peptide delivery}

When peptides are taken orally, they get degraded by enzymes. To avoid this limitation, transdermal delivery is applied, but a very less amount of peptide was successful in crossing the skin. Thus, MNs based peptide is now used to avoid such challenges by the skin barriers. For example, a desmopressin-based MN technique is used to deliver desmopressin safely and efficiently. Cyclosporin A, another cyclic peptide, was delivered using dissolving MNs having the dimension of $600 \mu \mathrm{m}$ in length and $250 \mu \mathrm{m}$ wide [42].

\section{Hormone delivery}

Some peptide hormone, such as insulin, was given via $\mathrm{MN}$ and showed decreased blood glucose levels than normal injections [43]. Li et al. cast solid MNs and checked the effect on blood glucose levels in diabetic mice. The outcome confirmed a decrease in blood glucose level to $29 \%$ of the initial value after 5 hours that concluded that enhanced permeability of insulin via MNs [44]. Ye and co-workers also investigated $\mathrm{MNs}$ with pancreatic $\beta$-cell.

\section{Ocular delivery}

Posterior segment symptoms can be minimized with the help of a targeted drug delivery system. The lontophoresis method was used to transport the nanoparticles into the suprachoroidal place, whereas without iontophoresis, the particles were found to be at the injection site. In combination with MN (>30\%) of nanoparticles moved successfully to the targeted site of action [45]. Singh et al. developed quick-dissolving polymeric $\mathrm{MNs}$ for intraocular drug delivery. MNs were cast by using PVP polymer having different molecular weights such as fluorescein, sodium, and fluorescein isothiocyanate-dextrans (MW of $70 \mathrm{kDa}$ and 150 $\mathrm{kDa}$ ). The system resulted in a fast dissolution rate, and in vitro testing of $\mathrm{MNs}$ concluded the permeability of the macromolecule. Furthermore, the confocal descriptions concluded that macromolecules formed depots within the tissues that result in sustained release of drugs [46]. Than et al. concluded self-implantable double-layered micro drug reservoirs for proficient and restricted ocular drug delivery. MNs can also be used as micro reservoirs to deliver the drug in a controlled manner. The study stated that antiangiogenic monoclonal antibody (DC101) could be transported by using an eye patch which results in 90\% reduction of the neovascular area and also offers synergistic effects [47]. In 2016, Khandan and his team had been aperture MNs for ocular drug delivery. The potential of MNs is enhanced up to 5fold [48]. Additionally, Kim and co-workers also reported $\mathrm{MNs}$ for site-specific antiglaucoma drug delivery [49].

\section{MNs as a sensor}

Recently a rising interest is seeing in the use of transdermal MN-based electrodes in favor of molecular-based bio-sensing and drug delivery [50]. As examples of MN-based biosensors have 
been explored for continuous screening of metabolic markers like glucose and lactate and organophosphate nerve agents [51]. These sensors can cross the SC only and therefore do not cause pain or draw blood, as they do not reach the nerve endings and capillary blood vessels in the dermis. The sensors offer less invasive for drug or metabolite controlling [52]. Gowers et al. cast an $\mathrm{MN}$-based sensor for continuous monitoring of $\beta$ lactam antibiotic concentrations in vivo. This sensor is coated with a $\mathrm{pH}$-dependent iridium oxide layer, indicating the alteration of $\mathrm{pH}$ [53]. Another MNs based array was described that regulates glucose level. Thus, MNs reduces several manifestations to check the glucose level in comparison with other devices [54]. Other MNs (nitrogen-based ultrananocrystalline diamond) have been developed for sensing, as stated by Skoog et al. This nitrogenbased sensor can sense electrochemical signals of dopamine and uric acid [55]. The MN-based biosensor was also used in electrical recognition, described by Keum et al., a promising platform for detecting cancer [56].

\section{MNs for drug delivery to the brain}

Several methods are already explored by which the BBB can be crossed to treat brain-associated diseases by using nanocarrier. Recently the MNs as a non-invasive technique are found to be more efficient in brain drug delivery. Kearney et al. investigated the donepezil hydrochloride entrapped MN patches to treat Alzheimer's diseases [57]. One more study was conducted about siliconbased MNs to transport the drug into the deep brain. In this regard, a silicon-based MN array was cast to recognize interlink as well as neuronal functions [58].

\section{Delivery of proteins}

Bovine serum albumin (BSA) is basically used as a model protein that is transported via microneedles [59]. Cheung et al. utilized the focused ion beam technique (FIB) to develop $\mathrm{MNs}$ and showed enhancement in the absorption of BSA by applying 'poke and patch technique. The study concluded that the absorption of BSA through the skin is only feasible while using a pre-perforation of the stratum corneum by using $\mathrm{MNs}$ to create a necessary passage for the protein [60]. Mönkäre et al. entrapped monoclonal lgG $(10 \% \mathrm{w} / \mathrm{w})$ in dissolving HA MNA. This procedure successfully passed the epidermis of ex vivo human skin, and after 10 min, the MNA was almost entirely dissolved [61].

\section{Cosmetics}

Having smooth and less invasive action onto the skin surface, MNs are widely used to treat different skinassociated problems such as seborrheic keratosis, scars, anti-aging, wrinkles, etc. 'Dermaroller' is one of the accepted examples of MNs based instrument. Machekposhti et al. developed MNs by utilizing PVP and methacrylic acid encapsulated with TXA. These MNs showed adequate properties for the management of melasma [62]. Hibrobe et al. prepared an ATRA-entrapped MN patch (ATRAMNs) for permeability enhancement of ATRA and MN patch loaded with retinoic acid. ATRA-MNs are used on the lesion site once per week for up to 4 weeks [63]. Triamcinolone acetonide-loaded MNs are also used reported by Chandrashekar et al. [64]. Administration of corticosteroids by using $\mathrm{MNs}$ showed enhanced blood supply to hair follicles [65]. Enhanced delivery of melanostatin, rigin, and palKTTKS was also investigated with the MNs [66]. Jingtong Pan et al. in 2018 concluded that dissolving MNs of STAT3 siRNA PEI complex has decreased the development of melanoma very efficiently and dose vulnerably by modifying the STAT3 gene. Therefore, the study concluded that dissolving MNs associated with STAT3 siRNA can be a promising way to treat skin melanoma with reduced side effects [67].

\section{MNs in transdermal drug delivery}

Owing to the drawbacks of the oral and traditional path of management, the transdermal patch has been broadly commonplace because of imperative characteristics that assist in attaining the required plasma concentration on the target site for an extended duration [68]. Thus, MNs are taken into consideration as a more promising tool for TDDS as micro-channels created via them allow the smooth and painless transport of therapeutics compared to that of hypodermic needles [69]. Wu et al. Fabricated sumatriptan succinate (SS)-loaded MN arrays from sodium hyaluronate to enhance their healing efficacy for transdermal shipping. Ramadan et al. Advanced polymeric lamivudine (LAM) loaded NPs for transdermal delivery thru passive diffusion and MN-mediated delivery was similarly investigated for long-term stability and penetration enhancement [70]. Yu et al. mentioned a glucoseresponsive insulin transport tool by the usage of a painless MN patch coined as a 'smart insulin patch' that carries glucose-responsive insulin and glucose oxidase (GOx) loaded vesicles. This clever and new insulin $\mathrm{MN}$ patch efficiently regulated blood glucose of chemically induced diabetes type 1 within the mouse version [71]. Zhao et al. defined $\mathrm{MNs}$ as a potential method in transdermal delivery and application within the management of psoriasis [72]. Niu et al. found that intradermal delivery with the aid of a hollow MN array creates a sustained launch depot within the pores and skin and might create a 
burst transit through draining lymph nodes [73]. Researchers have evolved MNPs to enhance the MTX remedy efficacy for psoriasis and decreased the facet effects because of MNs [74], [75]. Ajay K. Banga and teammates' works have stated that after MTX is carried out underneath MNP pre-treated skin, the delivery of MTX is more powerful than with significant strategies [76]. Korkmaz et al. advanced a type of DMN loaded with anti-TNF-a Ab in the pointers of the needles and determined that this method validated powerful delivery efficacy and anti-inflammation function in $B L A B / c$ mice with psoriatic lesions caused by using imiquimod [77].

\section{MNs in Cancer therapy}

Self-degradable Microneedles had been investigated for cancer treatment by using supplying over anti-PD-1 (aPD1) in a sustained manner. Anti-PD-1 and glucose oxidase-loaded pHtouchy dextran nanoparticles had been delivered through MN [78]. A topical cream containing five- fluorouracil is used to deal with basal cell carcinoma. The permeability of 5-fluorouracil turned into improved up to 4.5 instances whilst the cream becomes implemented on the pores and skin treated with stable MNs. Significant inhibition of tumor increase in addition confirmed improved efficacy the use of Microneedles [79]. Bhatnagar et al. investigated the shipping of chemotherapeutic retailers- tamoxifen and gemcitabine through MNs for the remedy of most breast cancers. Localized delivery of those pills might help to reduce the facet consequences [80]. Polymeric MNs were also investigated for skin cancer and localized delivery of anticancer capsules [81]. In Table 2 we've mentioned MNs applied in most cancers therapy [82-88].

\section{MNs in Diabetes}

$\mathrm{Yu}$ et al. established that glucose-responsive $\mathrm{MN}$ array patches regulated the glucose successfully in blood employing turning in insulin for type 1

Table 2. Application of MNs in Cancer Treatment

\begin{tabular}{|l|l|l|l|}
\hline Drug used & Type of study & Results & Reference \\
\hline Doxorubicin and docetaxel & In vivo & $\begin{array}{l}\text { Increased mice survival and impaired tumor } \\
\text { growth }\end{array}$ & {$[80]$} \\
\hline 5-Aminolevulinic acid & In vivo & Reduction of the tumor volume in 56\% & {$[82]$} \\
\hline Doxorubicin & Proof-of concept & Increased doxorubicin delivery across the skin & {$[83]$} \\
\hline Lipid-coated cisplatin nanoparticles & In vivo & $\begin{array}{l}\text { Stalled tumor progression and } \\
\text { increased skin safety }\end{array}$ & {$[84]$} \\
\hline Gold nano cubes and doxorubicin & In vivo & $\begin{array}{l}\text { Increased mice survival and impaired tumor } \\
\text { growth }\end{array}$ & {$[85]$} \\
\hline 5-Aminolevulinic acid & Reduction of the tumor volume in 70\% & {$[86]$} \\
\hline Doxorubicin and LaB6 nano materials & In vivo & $\begin{array}{l}\text { Complete eradication of the tumor and } \\
\text { increased mice survival }\end{array}$ & {$[87]$} \\
\hline 5-aminolevulinic acid & Proof-of concept & Increased the drug penetration in 2-fold & {$[88]$} \\
\hline
\end{tabular}

Table 3. Examples of marketed MNs-based products

\begin{tabular}{|c|c|c|c|}
\hline Name of product & Company & Description & Use \\
\hline Dermaroller ${ }^{\circledR}$ & $\begin{array}{l}\text { Dermaroller } \\
\text { Germany, White } \\
\text { Lotus }\end{array}$ & $\begin{array}{l}\text { A cylindrical roller with solid or metal micro- } \\
\text { needles, } \\
0.2-2.5 \mathrm{~mm} \text { in length. }\end{array}$ & $\begin{array}{l}\text { Enhance skin texture, } \\
\text { treat scars and hyper } \\
\text { pigmentation }\end{array}$ \\
\hline $\begin{array}{l}\text { C-8 } \\
\text { (Cosmetic type) }\end{array}$ & $\begin{array}{l}\text { The Dermaroller } \\
\text { Series by } \\
\text { Anastassakis K }\end{array}$ & A needle length of only $0.13 \mathrm{~mm}(130 \mu \mathrm{m})$ & $\begin{array}{l}\text { Used to improve penetration of } \\
\text { topical } \\
\text { agents }\end{array}$ \\
\hline $\begin{array}{l}\text { CIT-8 } \\
\text { (Collagen Induction } \\
\text { Therapy) }\end{array}$ & $\begin{array}{l}\text { The Dermaroller } \\
\text { Series by } \\
\text { Anastassakis K. }\end{array}$ & A needle length of $0.5 \mathrm{~mm}(500 \mu \mathrm{m})$ & $\begin{array}{l}\text { Used in collagen induction and } \\
\text { skin } \\
\text { remodeling. }\end{array}$ \\
\hline MF-8 type & $\begin{array}{l}\text { The Dermaroller } \\
\text { Series by } \\
\text { Anastassakis K. }\end{array}$ & A needle length of $1.5 \mathrm{~mm}(1500 \mu \mathrm{m})$ & Treat scars. \\
\hline MS-4 & $\begin{array}{l}\text { The Dermaroller } \\
\text { Series by } \\
\text { Anastassakis K }\end{array}$ & $\begin{array}{l}\text { A Small cylinder, } 1 \mathrm{~cm} \text { length, } 2 \mathrm{~cm} \text { diameter, } \\
\text { and } 4 \text { circulars } \\
\text { arrays of needles which are } 1.5 \mathrm{~mm} \text { in length }\end{array}$ & Used on facial acne scars \\
\hline Micro Hyala ${ }^{\circledR}$ & $\begin{array}{l}\text { CosMed } \\
\text { transdermal drug } \\
\text { delivery }\end{array}$ & $\begin{array}{l}\text { Dissolving micro-needle patch with } \\
\text { hyaluronic acid }\end{array}$ & Wrinkle treatment \\
\hline Lite Clear ${ }^{\circledR}$ & $\begin{array}{l}\text { Nano-med } \\
\text { skincare }\end{array}$ & $\begin{array}{l}\text { Solid silicon micro-needles are used as pre- } \\
\text { treatment and then } \\
\text { drug applied topically. }\end{array}$ & Treats acne and skin blemishes \\
\hline Soluvia ${ }^{\circledR}$ & $\begin{array}{l}\text { Sanofi Pasteur } \\
\text { Europe }\end{array}$ & $\begin{array}{l}\text { Hollow micro-needle } \\
\text { attached to a syringe }\end{array}$ & Influenza vaccination \\
\hline h-patch & Valeritas & Small adhesive machine-like patch is used & $\begin{array}{l}\text { To deliver drugs in } \\
\text { subcutaneous tissue } \\
\text { (insulin) }\end{array}$ \\
\hline
\end{tabular}


diabetes remedy [89]. Chen et al. developed a smart and $\mathrm{pH}$-responsive $\mathrm{MN}$ patch primarily based on alginate for type 2 diabetes therapies [90]. Lee et al. developed a portable electrochemical tool that monitors $\mathrm{pH}$, temperature, humidity, and the level of glucose timely in sweat yet also be actuated thermally to launch metformin transcutaneously for diabetes remedy [91].

\section{Accepted MNs based products}

The first MN-based formulation was the derma roller. Several MN-based products are available in the market which is used in medical and cosmetic purpose [92]. Captivatingly, MNs present important qualities rather than conventionally applied medication in transportation to the targeted site or systemic delivery. Hence, there had been a high expansion in scientific and industrial movement in this field from the earlier period. Some of them are described in Table 3. Many development companies from Germany, US, Europe, Japan are selling various $\mathrm{MNs}$ based formulations [93].

\section{Associated Patents}

From the previous decades, MNs were extensively used as potential release carriers. In this respect, the

Table 4. Micro-needle associated patents in pharmaceutical field

\begin{tabular}{|c|c|c|}
\hline Conditions or diseases & Patent number & Description \\
\hline $\begin{array}{l}\text { Electrochemical } \\
\text { biosensing in body fluid }\end{array}$ & $\begin{array}{l}13 / 2019 \\
201811044930\end{array}$ & $\begin{array}{l}\text { In this invention, it has developed a modern method for MNs that prints } \\
\text { assembled screens. Electrode fixes the bio-sensing electrode to print } \\
\text { the screen that sensing of blood glucose, cholesterol } \mathrm{HbA} 1 \mathrm{C} \text { and like. }\end{array}$ \\
\hline $\begin{array}{l}\text { Treatment of } \\
\text { hyperkeratosis, injury, and } \\
\text { pain in conditions like } \\
\text { warts, corns, calluses, } \\
\text { acne, psoriasis, keloids, } \\
\text { microtrauma, eczema }\end{array}$ & $\begin{array}{l}48 / 2018 \\
201721017985\end{array}$ & $\begin{array}{l}\text { The MNs patches based topical drug delivery system incorporated with } \\
\text { keratolytic agents. The patch comprises micron-scale protrusions that } \\
\text { penetrate via the SC and delivers the active pharmaceutical ingredient } \\
\text { across the SC to improve the permeation of drugs. A keratolytic agent } \\
\text { reduces the intercellular cohesiveness of the horny cells and thus } \\
\text { enables speedy shedding of keratinized cells [70]. }\end{array}$ \\
\hline Management of anxiety & $\begin{array}{l}42 / 2018 \\
2017201721013027\end{array}$ & $\begin{array}{l}\text { In this patent novel, the buspirone microemulsion method has } \\
\text { developed using the phase titration method and tested for its efficiency } \\
\text { in the skin. It enhances transdermal delivery. }\end{array}$ \\
\hline $\begin{array}{l}\text { Enhancement of } \\
\text { immunogenicity }\end{array}$ & $\mathrm{WO} / 2010 / 01360$ & $\begin{array}{l}\text { It has enhanced immunogenicity using an MNs for the Japanese } \\
\text { encephalitis virus antigen derived from kidney cells of monkey and } \\
\text { concluded that antibody against a Japanese encephalitis virus antigen } \\
\text { has efficiently enhanced. }\end{array}$ \\
\hline $\begin{array}{l}\text { Enhancing the } \\
\text { immunogenicity against } \\
\text { influenza virus }\end{array}$ & WO/2010/001671 & $\begin{array}{l}\text { Polylactic acid-coated MNs of an influenza vaccine that is the H1N1 } \\
\text { strain, } \mathrm{H} 3 \mathrm{~N} 2 \text { and types B strain, and brought into direct skin contact that } \\
\text { enhances immunogenicity against influenza virus. }\end{array}$ \\
\hline $\begin{array}{l}\text { To treat pimples, stains, or } \\
\text { wrinkles }\end{array}$ & 20150290163 & $\begin{array}{l}\text { MNs contain a substrate, water-swelling polymer, and retinoic acid. It } \\
\text { dissolves in an enormous amount of water. }\end{array}$ \\
\hline Local anaesthesia & 20200170940 & $\begin{array}{l}\text { The invention provides immediate acting local anesthetic MNs easily } \\
\text { applied to the oral cavity or site, In which a needle part dissolves in a } \\
\text { mucous membrane when applying to an oral mucous membrane or } \\
\text { gums. }\end{array}$ \\
\hline $\begin{array}{l}\text { Botulinum toxin to treat } \\
\text { diseases }\end{array}$ & 20170209553 & $\begin{array}{l}\text { To treat disease, disorder, or condition therapeutic amount of toxin was } \\
\text { added to the MN array [71]. }\end{array}$ \\
\hline Diagnosis of allergy & 20100030100 & $\begin{array}{l}\text { This is an invention of a diagnostic MN device for the detection of an } \\
\text { allergy. It holds at least one allergen that enables to perform skin tests } \\
\text { with an effortless process in the diagnosis of allergies. These MNs have } \\
\text { been prepared using non-metallic synthetic or natural resin material. }\end{array}$ \\
\hline
\end{tabular}


Table 5. Associated MNs under clinical trials

\begin{tabular}{|c|c|c|c|}
\hline Study Title & Interventions & Conditions & Status \\
\hline $\begin{array}{l}\text { MNs patch study in healthy infants/young } \\
\text { children }\end{array}$ & MNs Formulation 1 and 2 & $\begin{array}{l}\text { Vaccination } \\
\text { Skin absorption }\end{array}$ & Completed 2020 \\
\hline Pain and safety of MNs in the oral cavity & MNs & Oral cavity disease & Completed 2019 \\
\hline $\begin{array}{l}\text { Minimally invasive sensing of beta-lactam } \\
\text { antibiotics }\end{array}$ & $\begin{array}{l}\text { Phenoxymethyl } \\
\text { Penicillin, MNs }\end{array}$ & Healthy volunteers & Completed 2019 \\
\hline $\begin{array}{l}\text { Comparison of 1,550-nm laser and fractional } \\
\text { radiofrequency MNs for the treatment of acne } \\
\text { scars in ethnic skin }\end{array}$ & $\begin{array}{l}\text { Fraxel Restore and } \\
\text { Fractora }\end{array}$ & Acne scars & Completed 2019 \\
\hline $\begin{array}{l}\text { Analysis of noninvasively collected MN device } \\
\text { samples from mild plaque psoriasis for use in } \\
\text { transcriptomics profiling }\end{array}$ & MN device & Psoriasis vulgaris & Completed 2019 \\
\hline $\begin{array}{l}\text { Safety study of suprachoroidal triamcinolone } \\
\text { acetonide via MN to treat uveitis }\end{array}$ & $\begin{array}{l}\text { Triamcinolone, } \\
\text { acetonide }\end{array}$ & $\begin{array}{l}\text { Uveitis, intermediate, } \\
\text { uveitis, posterior } \\
\text { uveitis }\end{array}$ & Completed 2019 \\
\hline $\begin{array}{l}\text { A study of the use of MN patches to deliver } \\
\text { topical lidocaine in the oral cavity }\end{array}$ & MNs Patch & Topical anesthesia & Completed 2019 \\
\hline $\begin{array}{l}\text { The use of MNs to expedite treatment time in } \\
\text { photodynamic therapy }\end{array}$ & MN roller & Keratosis, actinic & Completed 2019 \\
\hline $\begin{array}{l}\text { A study to evaluate the long-term safety of } \\
\text { M207 in the acute treatment of migraine }\end{array}$ & M207 MNs System & Migraine & Completed 2019 \\
\hline $\begin{array}{l}\text { Safety and efficacy of ZP-zolmitriptan } \\
\text { intracutaneous MN systems for the acute } \\
\text { treatment of migraine }\end{array}$ & ZP-Zolmitriptan & Acute migraine & Completed 2018 \\
\hline $\begin{array}{l}\text { Clinical evaluation of healthy subjects } \\
\text { receiving intradermal saline using the MN } \\
\text { adapter (Model UAR-2S) }\end{array}$ & $\begin{array}{l}\text { MNs Adapter (Model } \\
\text { UAR-2S }\end{array}$ & Intradermal injection & Completed 2018 \\
\hline $\begin{array}{l}\text { The effect of MN pretreatment on topical } \\
\text { anesthesia }\end{array}$ & $\begin{array}{l}\text { Device: Sham MNs } \\
\text { Roller Device: MNs Roller }\end{array}$ & Pain & Completed 2018 \\
\hline $\begin{array}{l}\text { A split-mouth trial to compare MNs vs. } \\
\text { standard needles in dental anesthetic } \\
\text { delivery }\end{array}$ & MNs Device & $\begin{array}{l}\text { Dental pain } \\
\text { Anesthesia }\end{array}$ & Completed 2018 \\
\hline Glucose measurement using MN patches & MNs patch & Diabetes & Completed 2018 \\
\hline $\begin{array}{l}\text { The use of MNs with topical botulinum toxin } \\
\text { for the treatment of palmar hyperhidrosis }\end{array}$ & $\begin{array}{l}\text { Device: MNs } \\
\text { Device: Sham MNs }\end{array}$ & Hyperhidrosis & Completed 2017 \\
\hline The use of MNs in photodynamic therapy & MNs & Actinic keratosis & Completed 2017 \\
\hline Insulin delivery using MNs in type 1 diabetes & MNs & $\begin{array}{l}\text { Type } 1 \text { diabetes } \\
\text { mellitus }\end{array}$ & Completed 2014 \\
\hline $\begin{array}{l}\text { A study to assess the safety and efficacy of an } \\
\text { MNs device for local anesthesia }\end{array}$ & Micron Jet & $\begin{array}{l}\text { Local anesthesia } \\
\text { Intradermal injections }\end{array}$ & Completed 2013 \\
\hline $\begin{array}{l}\text { Optimization of tuberculosis intradermal skin } \\
\text { test }\end{array}$ & $\begin{array}{l}\text { MNs BD } 1.5 \\
\mathrm{~mm} \mathrm{30G}\end{array}$ & $\begin{array}{l}\text { MNs BD } 1.5 \\
\mathrm{~mm} 30 \mathrm{G}\end{array}$ & Completed 2013 \\
\hline $\begin{array}{l}\text { Pilocarpine Micro needles for Sweat Induction } \\
\text { (PMN-SI) }\end{array}$ & MNs patch & Cyclic fibrosis & Not yet recruiting \\
\hline MNs for Diagnosis of LTBI & $\begin{array}{l}\text { Diagnostic Test: TST vs } \\
\text { PPD microneedle test }\end{array}$ & Tuberculosis & Not yet recruiting \\
\hline
\end{tabular}


researcher gives much more concentration to the survey to progress the MNs material and its properties. Thus, it can be proficiently used for the effectual delivery of therapeutics with low side effects. Several patents related to MNs are present in the drug delivery system. The inventive approach for targeted drug delivery of active agent through MNs associated patents are showed in Table 4.

\section{Clinical trials}

Various clinical trials were conducted on $\mathrm{MNs}$ and resulted in an efficient role in many respective though a limited number has been accepted for human subjects. Kaushik et al. conducted the first research on MNs in human subjects in the year 2001. The motto was to check whether the silicon MNs can avoid pain compared to a 26-gauge hypodermic needle or not. The result showed that the pain developed by the MNs was lower than that of hypodermic needles [94]. Arya and his teammates also did research to evaluate whether MNs cause local skin irritation or not. The study was conducted among 15 human volunteers and found micro needles did not cause any swelling, pain, or erythema at the site of application of the patch. The patients were able to self-administer the patches without difficulty [95]. An open trial was conducted among 10 patients for hyaluronic acid-based MN patches to evaluate the therapeutic efficacy against psoriasis. Calcipotriol-betamethasone ointment was useful on the skin. MN patch is used once a day for a week. The result showed a considerable decrease in the psoriatic plaques and thus concluded MNs are a better option than conventional cream applications [96]. This promising method is flexible enough and can be used to deliver proteins up to $100 \mathrm{mg}$ that can go straight into the blood circulation [97]. In Table 5 the MNs under clinical trials has been described [98]

\section{Conclusion}

Even though multiple drug delivery systems have been designed for targeted delivery, MNs are still unique due to their multipurpose advantages. The transportation of bio-actives by using $\mathrm{MNs}$ has shown the revolutionary window for life-threatening illnesses. The MNs have already been confirmed to be a more effective and safe method of drug delivery systems. Overall, the application of MNs becomes more famous, and a large number of research works is going. Several research and literatures have described the significance of $\mathrm{MNs}$ in the case of drug delivery via a different route of administration. Still, there is a need for more research about MNs for future multipurpose use in pharmacy.

\section{Conflict of Interest}

All the authors declare no conflict of interest.

\section{Funding}

Not applicable

\section{References}

1. Dugam S, Tade R, Dhole R, Nangare S. Emerging era of microneedle array for pharmaceutical and biomedical applications: recent advances and toxicological perspectives. Future Journal of Pharmaceutical Sciences. 2021 Dec; 7(1):1-26.

2. Nangare S, Tade RS, Dugam S, Shitole MM. Progress in erectile dysfunction therapy via drug delivery system. Thai Journal of Pharmaceutical Sciences (TJPS). 2020 Jun 15; 44(2).

3. Barry BW. Novel mechanisms and devices to enable successful transdermal drug delivery. European journal of pharmaceutical sciences. 2001 Sep 1; 14(2):101-14.

4. Tabassum N, Sofi A, Khuroo T. Microneedle technology: a new drug delivery system. Int J Res Pharm Biomed Sci. 2011; 2(1):59-62.

5. Donnelly RF, Singh TR, Woolfson AD. Microneedle-based drug delivery systems: microfabrication, drug delivery, and safety. Drug delivery. 2010 May 1; 17(4):187-207.

6. Mogusala NR, Devadasu VR, Venisetty RK. Fabrication of microneedle molds and polymer based biodegradable microneedle patches: a novel method. American Journal of Drug Delivery and Therapeutics. 2015; 2(2).

7. Prausnitz MR, Mitragotri S, Langer R. Current status and future potential of transdermal drug delivery. Nature reviews Drug discovery. 2004 Feb; 3(2):115-24.

8. Xie L, Zeng $H$, Sun J, Qian W. Engineering microneedles for therapy and diagnosis: a survey. Micromachines. 2020 Mar; 11(3):271.

9. Du G, Sun X. Current advances in sustained release microneedles. Pharmaceutical Fronts. 2020 Mar; 2(01):e11-22.

10.Verbaan FJ, Bal SM, Van den Berg DJ, Groenink WH, Verpoorten $H$, Lüttge $R$, Bouwstra JA. Assembled microneedle arrays enhance the transport of compounds varying over a large range of molecular weight across human 
dermatomed skin. Journal of Controlled Release. 2007 Feb 12; 117(2):238-45.

11.Waghule T, Singhvi G, Dubey SK, Pandey MM, Gupta G, Singh M, Dua K. Micro needles: A smart approach and increasing potential for transdermal drug delivery system. Biomedicine \& pharmacotherapy. 2019 Jan 1; 109:1249-58.

12.Larraneta $E$, Lutton RE, Woolfson AD, Donnelly RF. Microneedle arrays as transdermal and intradermal drug delivery systems: Materials science, manufacture and commercial development. Materials Science and Engineering: R: Reports. 2016 Jun 1; 104:1-32.

13. Hong X, Wei L, Wu F, Wu Z, Chen L, Liu Z, Yuan W. Dissolving and biodegradable microneedle technologies for transdermal sustained delivery of drug and vaccine. Drug design, development and therapy. 2013; 7: 945.

14.Niinomi M, Nakai M. Titanium-based biomaterials for preventing stress shielding between implant devices and bone. International journal of biomaterials. 2011 Jan 1; 2011.

15.Pignatello R, editor. Biomaterials: applications for Nanomedicine. BoD-Books on Demand; 2011 Nov 16.

16.Gittard SD, Narayan RJ, Jin C, Monteiro-Riviere NA, Ovsianikov A, Chichkov BN, Stafslien S, Chisholm B. Pulsed laser deposition of antimicrobial silver coating on Ormocer (registered) microneedles. Biofabrication (Online). 2009 Dec 15; 1.

17.Perennes F, Marmiroli B, Matteucci M, Tormen M, Vaccari L, Di Fabrizio E. Sharp beveled tip hollow microneedle arrays fabricated by LIGA and 3D soft lithography with polyvinyl alcohol. Journal of Micromechanics and Micro engineering. 2006 Jan 25;16(3):473.

18.Aoyagi S, Izumi $\mathrm{H}$, Isono $Y$, Fukuda M, Ogawa $\mathrm{H}$. Laser fabrication of high aspect ratio thin holes on biodegradable polymer and its application to a microneedle. Sensors and Actuators A: Physical. 2007 Sep 12;139(1-2):293-302.

19.Park JH, Allen MG, Prausnitz MR. Polymer microneedles for controlled-release drug delivery. Pharmaceutical research. 2006 May;23(5):1008-19.

20.Chu LY, Choi SO, Prausnitz MR. Fabrication of dissolving polymer microneedles for controlled drug encapsulation and delivery: bubble and pedestal microneedle designs. Journal of pharmaceutical sciences. 2010 Oct 1;99(10):4228-38.

21.Donnelly RF, Majithiya R, Singh TR, Morrow DI, Garland MJ, Demir YK, Migalska K, Ryan E, Gillen $D$, Scott CJ, Woolfson AD. Design, optimization and characterisation of polymeric microneedle arrays prepared by a novel laser-based micro moulding technique. Pharmaceutical research. 2011 Jan;28(1):41-57.

22. Miyano $T$, Tobinaga $Y$, Kanno $T$, Matsuzaki $Y$, Takeda H, Wakui M, Hanada K. Sugar micro needles as transdermic drug delivery system. Biomedical Micro devices. 2005 Sep; 7(3):185-8.

23. Mao J, Wang H, Xie Y, Fu Y, Li Y, Liu P, Du H, Zhu J, Dong L, Hussain M, Li Y. Transdermal delivery of rapamycin with poor water-solubility by dissolving polymeric microneedles for anti-angiogenesis. Journal of Materials Chemistry B. 2020; 8(5):92834.

24.Nguyen HX, Banga AK. Enhanced skin delivery of vismodegib by microneedle treatment. Drug delivery and translational research. 2015 Aug; 5(4):407-23.

25.Katsumi, H., Liu, S., Tanaka, Y., Hitomi, K., Hayashi, R., Hirai, Y., Kusamori, K., Quan, Y.S., Kamiyama, F., Sakane, T. and Yamamoto, A., 2012. Development of a novel self-dissolving microneedle array of alendronate, a nitrogencontaining bisphosphonate: evaluation of transdermal absorption, safety, and pharmacological effects after application in rats. Journal of pharmaceutical sciences, 101(9), pp.3230-3238.

26.Sharma D. Micro needles: an approach in transdermal drug delivery: a Review. Pharma Tutor. 2018 Jan 1; 6(1):7-15.

27.Akhtar N. Micro needles: an innovative approach to transdermal delivery-a review. Int. J. Pharm. Pharm. Sci. 2014; 6(4):18-25.

28.Suzuki M, Takahashi T, Aoyagi S. 3D laser lithographic fabrication of hollow microneedle mimicking mosquitos and its characterisation. International Journal of Nanotechnology. 2018; 15(1-3):157-73.

29.Cheung K, Han T, Das DB. Effect of force of microneedle insertion on the permeability of insulin in skin. Journal of diabetes science and technology. 2014 May; 8(3):444-52.

30.Larraneta E, Lutton RE, Woolfson AD, Donnelly RF. Microneedle arrays as transdermal and intradermal drug delivery systems: Materials 
science, manufacture and commercial development. Materials Science and Engineering: R: Reports. 2016 Jun 1; 104:1-32.

31.Narayanan SP, Raghavan S. Fabrication and characterization of gold-coated solid silicon microneedles with improved biocompatibility. The International Journal of Advanced Manufacturing Technology. 2019 Oct; 104(9):3327-33.

32.Manoj VR, Manoj HI. Review on transdermal microneedle-based drug delivery. Asian J Pharm Clin Res. 2019; 12(1):18-29.

33.Bora P, Kumar L, Bansal AK. Microneedle technology for advanced drug delivery: Evolving vistas. Review Article, Deaprtment of Pharmaceutical Technology, NIPER, CRIPS. 2008 Jan; 9(1).

34.Lin W, Cormier M, Samiee A, Griffin A, Johnson B, Teng $\mathrm{CL}$, Hardee GE, Daddona PE. Transdermal Delivery of Antisense Oligonucleotides with Microprojection Patch (Macroflux ${ }^{\circledR}$ ) Technology. Pharmaceutical research. 2001;18(12):1789-93.

35.Prausnitz MR. Engineering microneedle patches for vaccination and drug delivery to skin. Annual review of chemical and biomolecular engineering. 2017 Jun 7;8:177-200.

36. Mikszta JA, Alarcon JB, Brittingham JM, Sutter DE, Pettis RJ, Harvey NG. Improved genetic immunization via micromechanical disruption of skin-barrier function and targeted epidermal delivery. Nature medicine. 2002 Apr;8(4):415-9.

37.Mistilis MJ, Bommarius AS, Prausnitz MR. Development of a thermostable microneedle patch for influenza vaccination. Journal of pharmaceutical sciences. 2015 Feb 1; 104(2):7409.

38.Rodgers AM, Courtenay AJ, Donnelly RF. Dissolving microneedles for intradermal vaccination: manufacture, formulation, and stakeholder considerations. Expert opinion on drug delivery. 2018 Nov 2; 15(11):1039-43.

39.Zhu DD, Zhang XP, Yu HL, Liu RX, Shen CB, Zhang WF, Cui Y, Guo XD. Kinetic stability studies of HBV vaccine in a microneedle patch. International journal of pharmaceutics. 2019 Aug 15; 567:118489.

40.Littauer EQ, Mills LK, Brock N, Esser ES, Romanyuk A, Pulit-Penaloza JA, Vassilieva EV, Beaver JT, Antao O, Krammer F, Compans RW. Stable incorporation of GM-CSF into dissolvable microneedle patch improves skin vaccination against influenza. Journal of Controlled Release. 2018 Apr 28; 276:1-6.

41.Ali R, Mehta P, Arshad MS, Kucuk I, Chang MW, Ahmad Z. Transdermal microneedles-a materials perspective. Aaps PharmSciTech. 2020 Jan; 21(1):1-4.

42.Jeong HR, Kim JY, Kim SN, Park JH. Local dermal delivery of cyclosporin A, a hydrophobic and high molecular weight drug, using dissolving microneedles. European Journal of Pharmaceutics and Biopharmaceutics. 2018 Jun 1; 127:237-43.

43. Martanto W, Davis SP, Holiday NR, Wang J, Gill HS, Prausnitz MR. Transdermal delivery of insulin using microneedles in vivo. Pharmaceutical research. 2004 Jun; 21(6):947-52.

44.Li QY, Zhang JN, Chen BZ, Wang QL, Guo XD. A solid polymer microneedle patch pretreatment enhances the permeation of drug molecules into the skin. Rsc Advances. 2017;7(25):15408-15.

45.Jung JH, Chiang B, Grossniklaus HE, Prausnitz MR. Ocular drug delivery targeted by iontophoresis in the suprachoroidal space using a microneedle. Journal of Controlled Release. 2018 May 10; 277:14-22.

46.Thakur RR, Tekko IA, Al-Shammari F, Ali AA, McCarthy $H$, Donnelly RF. Rapidly dissolving polymeric microneedles for minimally invasive intraocular drug delivery. Drug delivery and translational research. $2016 \mathrm{Dec} ; 6(6): 800-15$.

47.Than A, Liu C, Chang H, Duong PK, Cheung CM, Xu C, Wang X, Chen P. Self-implantable doublelayered micro-drug-reservoirs for efficient and controlled ocular drug delivery. Nature communications. 2018 Nov 6; 9(1):1-2.

48.Ali R, Mehta P, Arshad MS, Kucuk I, Chang MW, Ahmad Z. Transdermal microneedles-a materials perspective. Aaps Pharmscitech. 2020 Jan; 21(1):1-4.

49.Kang-Mieler JJ, Rudeen KM, Liu W, Mieler WF. New Ocular Drug Delivery Systems. In Macular Surgery 2020 (pp. 577-591). Springer, Singapore. 50. Cha KJ, Kim T, Park SJ, Kim DS. Simple and costeffective fabrication of solid biodegradable polymer microneedle arrays with adjustable aspect ratio for transdermal drug delivery using acupuncture microneedles. Journal of Micromechanics and Micro engineering. 2014 Oct 16; 24(11):115015.

51.Mishra RK, Mohan AV, Soto F, Chrostowski R, Wang J. A microneedle biosensor for minimally- 
invasive transdermal detection of nerve agents. Analyst. 2017; 142(6):918-24.

52.Sharma S, El-Laboudi A, Reddy M, Jugnee N, Sivasubramaniyam S, El Sharkawy M, Georgiou P, Johnston D, Oliver N, Cass AE. A pilot study in humans of microneedle sensor arrays for continuous glucose monitoring. Analytical Methods. 2018; 10(18): 2088-95.

53. Gowers SA, Freeman DM, Rawson TM, Rogers ML, Wilson RC, Holmes AH, Cass AE, O'Hare D. Development of a minimally invasive microneedle-based sensor for continuous monitoring of $\beta$-lactam antibiotic concentrations in vivo. ACS sensors. 2019 Apr 5; 4(4):1072-80.

54.Sharma S, Takagi E, Cass T, Tsugawa W, Sode K. Minimally invasive microneedle array electrodes employing direct electron transfer type glucose dehydrogenase for the development of continuous glucose monitoring sensors. Procedia technology. 2017 Jan 1; 27:208-9.

55.Skoog SA, Miller PR, Boehm RD, Sumant AV, Polsky R, Narayan RJ. Nitrogen-incorporated ultrananocrystalline diamond microneedle arrays for electrochemical biosensing. Diamond and Related Materials. 2015 Apr 1; 54:39-46.

56.Keum DH, Jung HS, Wang T, Shin MH, Kim YE, Kim $\mathrm{KH}$, Ahn GO, Hahn SK. Microneedle Biosensor for Real-Time Electrical Detection of Nitric Oxide for In Situ Cancer Diagnosis During Endomicroscopy. Advanced healthcare materials. 2015 Jun; 4(8):1153-8.

57.Kearney MC, Caffarel-Salvador E, Fallows SJ, McCarthy HO, Donnelly RF. Microneedlemediated delivery of donepezil: potential for improved treatment options in Alzheimer's disease. European Journal of Pharmaceutics and Biopharmaceutics. 2016 Jun 1; 103:43-50.

58.Lee HJ, Son Y, Kim D, Kim YK, Choi N, Yoon ES, Cho IJ. A new thin silicon microneedle with an embedded microchannel for deep brain drug infusion. Sensors and Actuators B: Chemical. 2015 Mar 31; 209:413-22.

59.van der Maaden K, Jiskoot W, Bouwstra J. Microneedle technologies for (trans) dermal drug and vaccine delivery. Journal of controlled release. 2012 Jul 20; 161(2):645-55.

60.Cheung K, West G, Das DB. Delivery of large molecular protein using flat and short microneedles prepared using focused ion beam (FIB) as a skin ablation tool. Drug delivery and translational research. 2015 Aug; 5(4):462-7.
61.Mönkäre J, Nejadnik MR, Baccouche K, Romeijn S, Jiskoot W, Bouwstra JA. IgG-loaded hyaluronanbased dissolving microneedles for intradermal protein delivery. Journal of controlled release. 2015 Nov 28; 218:53-62.

62. Machekposhti SA, Soltani M, Najafizadeh $P$, Ebrahimi SA, Chen P. Biocompatible polymer microneedle for topical/dermal delivery of tranexamic acid. Journal of Controlled Release. 2017 Sep 10; 261:87-92.

63. Hirobe S, Otsuka R, lioka H, Quan YS, Kamiyama F, Asada H, Okada N, Nakagawa S. Clinical study of a retinoic acid-loaded microneedle patch for seborrheic keratosis or senile lentigo. Life sciences. 2017 Jan 1; 168:24-7.

64.Chandrashekar BS, Yepuri V, Mysore V. Alopecia areata-successful outcome with microneedling and triamcinolone acetonide. Journal of cutaneous and aesthetic surgery. 2014; 7(1):63.

65.Alsantali A. Alopecia areata: a new treatment plan. Clinical, cosmetic and investigational dermatology. 2011; 4:107.

66. Mohammed YH, Yamada M, Lin LL, Grice JE, Roberts MS, Raphael AP, Benson HA, Prow TW. Microneedle enhanced delivery of cosmeceutically relevant peptides in human skin. PloS one. 2014 Jul 17; 9(7):e101956.

67.Pan J, Ruan W, Qin M, Long Y, Wan T, Yu K, Zhai Y, Wu C, Xu Y. Intradermal delivery of STAT3 siRNA to treat melanoma via dissolving microneedles. Scientific reports. 2018 Jan 18; $8(1): 1-1$

68.Nangare S, Dhananjay B, Mali R, Shitole M. Development of novel freeze-dried mulberry leaves extract-based transfersomal gel. Turk J Pharm Sci. https://doi. org/10.4274/tjps. 2019 Dec 5; 98624.

69.Park JH, Allen MG, Prausnitz MR. Biodegradable polymer Microneedles: fabrication, mechanics and transdermal drug delivery. Journal of controlled release. 2005 May 5; 104(1):51-66

70.Ramadan E, Borg T, Abdelghani GM, Saleh NM. Transdermal microneedle-mediated delivery of polymeric lamivudine-loaded nanoparticles. J. Pharm. Technol. Drug Res. 2016 Mar 30; 5(1).

71.Yu J, Zhang Y, Gu Z. Glucose-responsive insulin delivery by microneedle-array patches loaded with hypoxia-sensitive vesicles. In Biomedical Nanotechnology 2017 (pp. 251-259). Humana Press, New York, NY. 
72.Zhao Z, Chen Y, Shi Y. Microneedles: a potential strategy in transdermal delivery and application in the management of psoriasis. RSC Advances. 2020; 10(24):14040-9.

73. Niu L, Chu LY, Burton SA, Hansen KJ, Panyam J. Intradermal delivery of vaccine nanoparticles using hollow microneedle array generates enhanced and balanced immune response. Journal of controlled release. 2019 Jan 28; 294:268-78.

74. Vemulapalli V, Yang Y, Friden PM, Banga AK. Synergistic effect of iontophoresis and soluble Microneedles for transdermal delivery of methotrexate. Journal of Pharmacy and Pharmacology. 2008 Jan; 60(1):27-33.

75.Du H, Liu P, Zhu J, Lan J, Li Y, Zhang L, Zhu J, Tao J. Hyaluronic acid-based dissolving microneedle patch loaded with methotrexate for improved treatment of psoriasis. ACS applied materials \& interfaces. 2019 Oct 25; 11(46):43588-98

76.Nguyen HX, Banga AK. Delivery of methotrexate and characterization of skin treated by fabricated PLGA micro needles and fractional ablative laser. Pharmaceutical research. 2018 Mar; 35(3):1-20.

77.Korkmaz E, Friedrich EE, Ramadan MH, Erdos G, Mathers AR, Ozdoganlar OB, Washburn NR, Falo Jr LD. Therapeutic intradermal delivery of tumor necrosis factor-alpha antibodies using tip-loaded dissolvable microneedle arrays. Acta biomaterialia. 2015 Sep 15; 24:96-105.

78.Wang C, Ye Y, Hochu GM, Sadeghifar H, Gu Z. Enhanced cancer immunotherapy by micro needle patch-assisted delivery of anti-PD1 antibody. Nano letters. 2016 Apr 13; 16(4):233440.

79.Naguib YW, Kumar A, Cui Z. The effect of Micro needles on the skin permeability and antitumor activity of topical 5-fluorouracil. Acta Pharmaceutica Sinica B. 2014 Feb 1; 4(1):94-9.

80.Bhatnagar S, Kumari P, Pattarabhiran SP, Venuganti VV. Zein micro needles for localized delivery of chemotherapeutic agents to treat breast cancer: drug loading, release behavior, and skin permeation studies. AAPS Pharm SciTech. 2018 May; 19(4):1818-26.

81.Ye Y, Wang C, Zhang X, Hu Q, Zhang Y, Liu Q, Wen D, Milligan J, Bellotti A, Huang L, Dotti G. A melanin-mediated cancer immunotherapy patch. Science immunology. 2017 Nov 10; 2(17).

82.Zhao X, Li X, Zhang P, Du J, Wang Y. Tip-loaded fast-dissolving micro needle patches for photodynamic therapy of subcutaneous tumor. Journal of controlled release. 2018 Sep 28; 286:201-9.

83.Nguyen HX, Bozorg BD, Kim Y, Wieber A, Birk G, Lubda D, Banga AK. Poly (vinyl alcohol) micro needles: fabrication, characterization, and application for transdermal drug delivery of doxorubicin. European journal of pharmaceutics and biopharmaceutics. 2018 Aug 1; 129:88-103.

84.Lan X, She J, Lin DA, Xu Y, Li X, Yang WF, Lui VW, Jin $L$, Xie $X$, Su YX. Micro needle-mediated delivery of lipid-coated cisplatin nanoparticles for efficient and safe cancer therapy. ACS applied materials \& interfaces. 2018 Sep 11; 10(39):33060-9.

85.Dong L, Li Y, Li Z, Xu N, Liu P, Du H, Zhang Y, Huang $Y$, Zhu J, Ren $G$, Xie J. Au nanocagestrengthened dissolving micro needles for chemo-photothermal combined therapy of superficial skin tumors. ACS applied materials \& interfaces. 2018 Mar 1; 10(11):9247-56.

86.Jain AK, Lee CH, Gill HS. 5-Aminolevulinic acid coated microneedles for photodynamic therapy of skin tumors. Journal of Controlled Release. 2016 Oct 10; 239:72-81.

87.Chen MC, Lin ZW, Ling MH. Near-infrared lightactivatable microneedle system for treating superficial tumors by combination of chemotherapy and photothermal therapy. ACS nano. 2016 Jan 26;10(1):93-101.

88.Donnelly RF, Morrow DI, McCarron PA, Woolfson $A D$, Morrissey $A$, Juzenas $P$, Juzeniene $A$, lani $V$, McCarthy HO, Moan J. Micro needle-mediated intradermal delivery of 5-aminolevulinic acid: potential for enhanced topical photodynamic therapy. Journal of Controlled Release. 2008 Aug 7; 129(3):154-62.

89.Yu J, Zhang $Y, Y e ~ Y$, Isanti R, Sun W, Ranson D, Ligler FS, Buse JB, Gu Z. Micro needle-array patches loaded with hypoxia-sensitive vesicles provide fast glucose-responsive insulin delivery. Proceedings of the National Academy of Sciences. 2015 Jul 7; 112(27):8260-5.

90.Chen W, Tian R, Xu C, Yung BC, Wang G, Liu Y, Ni Q, Zhang F, Zhou Z, Wang J, Niu G. Micro needlearray patches loaded with dual mineralized protein/peptide particles for type 2 diabetes therapy. Nature communications. 2017 Nov 24; $8(1): 1-1$.

91.Lee H, Choi TK, Lee YB, Cho HR, Ghaffari R, Wang L, Choi HJ, Chung TD, Lu N, Hyeon T, Choi SH. A 
graphene-based electrochemical device with thermo responsive micro needles for diabetes monitoring and therapy. Nature nanotechnology. 2016 Jun; 11(6):566-72.

92.Singh A, Yadav S. Micro needling: advances and widening horizons. Indian dermatology online journal. 2016 Jul; 7(4):244.

93. Hong X, Wei L, Wu F, Wu Z, Chen L, Liu Z, Yuan W. Dissolving and biodegradable microneedle technologies for transdermal sustained delivery of drug and vaccine. Drug design, development and therapy. 2013; 7:945.

94.Dugam S, Tade R, Dhole R, Nangare S. Emerging era of microneedle array for pharmaceutical and biomedical applications: recent advances and toxicological perspectives. Future Journal of Pharmaceutical Sciences. 2021 Dec; 7(1):1-26.

95.Kaspar RL, Speaker T, inventors; TRANSDERM Inc, assignee. Delivery of botulinum with microneedle arrays. United States patent application US 15/331,469. $2017 \mathrm{Jul} 27$.

96.Kaushik S, Hord AH, Denson DD, McAllister DV, Smitra S, Allen MG, Prausnitz MR. Lack of pain associated with microfabricated microneedles. Anesthesia \& Analgesia. 2001 Feb 1; 92(2):502-4.

97.Arya J, Henry S, Kalluri H, McAllister DV, Pewin WP, Prausnitz MR. Tolerability, usability and acceptability of dissolving microneedle patch administration in human subjects. Biomaterials. 2017 Jun $1 ;$ 128:1-7.

98.https://www.clinicaltrials.gov/ct2/results 